\title{
Long Luteal Agonist Tedavi Protokolü Uygulanan IVF Sikluslarında, Hipofizer Baskılanma Sonucu Bakılan Antral Folikül Sayısı, FSH Değerleri Ve FSH/LH Oranlarının Siklus Performansını Öngörmedeki Rolü
}

\author{
The Role Of The AFC, FSH, FSH/LH Values, In Normal Responder Patients, After Hypophysis \\ Supression In Long Luteal Gnrh Agonist Protocols For IVF, In The Prediction Of Cycle \\ Performance Of The IVF Cycles. \\ Aşkı Ellibeş KAYA', Serdar DílBAZ² ${ }^{2}$ Emine Seda Güvendağ GÜVEN${ }^{3}$, Burak KARADAĞ ${ }^{4}$, \\ Berfu DEMiR ${ }^{5}$ \\ 'Çorum Özel Hastanesi, Kadın Hastalıkları ve Doğum Kliniği, Çorum \\ ${ }^{2}$ Düzce Üniversitesi Tıp Fakültesi, Kadın Hastalıkları ve Doğum AD, Düzce \\ ${ }^{3}$ Recep Tayyip Erdoğan Üniversitesi Tıp Fakültesi, Kadın Hastalıkları ve Doğum AD, Rize \\ ${ }^{4}$ T.C. Sağlık Bakanlığı Ankara Eğitim ve Araştırma Hastanesi, Kadın Hastalıkları ve Doğum Kliniği, Ankara \\ ${ }^{5}$ T.C. Sağlık Bakanlığı Ankara Etlik Zübeyde Hanım Kadın Hastalıkları Eğitim ve Araştırma Hastanesi, Kadın Hastalıkları \\ ve Doğum Kliniği, Ankara
}

\section{Öz}

Amaç: In vitro fertilizasyonun (IVF) başarısını en çok etkileyen faktörlerin başında; yaş ve tüm değişkenlerden bağımsız olarak over rezervi gelmektedir.

Bu çalışmanın amacı; normal cevaplı olduğu düşünülen, GnRH long luteal agonist protokolü kullanılan IVF sikluslarında hipofizer baskılanma esnasında over rezervi değerlendirme testlerinden antral folikül sayısı, FSH, FSH/ LH değerlerinin siklus performansını öngörmedeki rollerini araştırmaktır.

Gereç ve Yöntem: Çalışmaya kontrollü ovaryen hiperstimülasyon $(\mathrm{KOH})$ ve intrasitoplazmik sperm enjeksiyonu (ICSI) işlemi uygulanan ve GnRH long luteal agonist tedavi protokolü başlanan 78 infertil çift dahil edildi. Tüm hastalar için yaş, vücut kütle indeksi (BMi), tedavi süresince kullanılan toplam gonadotropin miktarı, stimülasyon süresi, toplam oosit sayısı, matür oosit sayısı, oosit kalite indeks değerleri, 2 PN (2 pronucleus) sayısı, 2. 3. ve 5. gün embriyo skorları, stimülasyonun 4. günündeki E2 seviyeleri, HCG günü E2 seviyeleri ve gebelik oranları kaydedildi.

Bulgular: Bazal FSH ile $\mathrm{KOH}$ süresi ve 2 PN arasında istatistiksel anlamlı korelasyon saptandı. Bazal FSH arttıkça $\mathrm{KOH}$ süresinin arttığı, 2PN sayısının azaldığı tespit edildi $[(p=0,04),(p=0,01)]$. Bazal AFS arttıkça toplam kullanılan gonadotropin miktarının azaldığı saptandı $(p=0,007)$.

Sonuç: IVF sikluslarında normal cevaplı olduğu kabul edilen, GnRH long luteal agonist protokolü başlanılan vakalarda bAFS, bFSH ve bFSH/LH değerleri ile bazal AFS; bazal FSH, bazal FSH/LH arasında siklus performansını öngörmede anlamlı bir fark olmadığı sonucuna varıldı.

Anahtar Kelimeler: GnRH agonisti; hipofiz supresyonu; over rezerv testleri; antral folikül sayımı; in vitro fertilizasyon.

\section{ABSTRACT}

Objective: The predominant factors that affect the success of in vitro fertilization (IVF) cycles are age and ovarian reserve of the patient. The aim of this study is; to determine the role the AFC, FSH, FSH/LH values, after hypophysis supression in long luteal $\mathrm{GnRH}$ agonist protocol, in the prediction of performance of the IVF cycles.

Material and Methods: Seventy eight patients who underwent $\mathrm{COH}$ and $\mathrm{GnRH}$ long luteal agonist protocol were recruited for the study. For all the patients; age, body mass index (BMI), basal antral follicule count (AFC), overall gonadotrophin required, duration of the induced cycle, number of collected oocytes, number of the mature oocytes, oocyte quality index, number of 2 Pronucleus (2PN), E2 levels on the fourth day of stimulation and HCG day, 2., 3. and 5. day embryo scores and the pregnancy rates were recorded.

Results: There were statistically significant correlation between basal FSH and number of 2PN; basal FSH and duration of the induced cycle $(p=0,04, p=0,01)$. A negative correlation is found between basal AFC and the amount of gonadotropin required $(p=0,007)$.

Conclusion: In normoresponsive patients, there were no statistically significant difference between basal AFC, FSH, $\mathrm{FSH} / \mathrm{LH}$ values and suppressed $\mathrm{AFC}, \mathrm{FSH}, \mathrm{FSH} / \mathrm{LH}$ values in the prediction of performance of the IVF cycles in long luteal GnRH Agonist protocol.

Keywords: GnRH agonist; hypophyseal supression; ovarian reserve tests; antral follicle count; in vitro fertilization. 


\section{GíRiş}

In vitro fertilizasyonun (IVF) başarısını en çok etkileyen faktör; tüm değişkenlerden bağımsız olarak over rezervidir. Over rezervi; overlerde follikülogenez ve steroidogenez fonksiyonunu yerine getirecek foliküllerin sayı, kalite ve yeterliliğini tanımlamaktadır. Over rezervi kadının fertilizasyon yeteneğiyle ilişkilidir. İleri yaş, geçirilmiş ovaryen cerrahi, şiddetli endometriozis, obezite, sigara içimi, adezyon ve frozen pelvis gibi anatomik bozukluklar, latent veya prematur ovarianyetmezlikover rezervinde azalmaya sebep olan faktörlerdir (1). Yapılan çalışmalarda;sikluslararasıover rezervtestlerinin sonuçlarındaki dalgalanmaların hipotalamohipofizer akstan kaynaklandığından yola çıkarak; IVF sikluslarında long luteal agonist kullanılan vakalarda hipofizer baskılanma gerçekleştirildikten sonra, over rezerv testleri tekrarlanmış, anlamlı sonuçlar elde edilmiştir (2).

$\mathrm{Bu}$ çalışmanın amacl; yapılan ön tetkikler sonucunda normal cevaplı olduğu düşünülen, GnRH long luteal agonist protokolü kullanılan IVF sikluslarında, hipofizer baskılanma esnasında over rezerv testlerinden antral folikül sayısı, FSH, FSH/LH değerlerinin siklus performansı üzerine etkilerini araştırmaktır.

\section{GEREÇ ve YÖNTEM}

Hastanemiz Eğitim ve Planlama Kurulu tarafından 24 Kasım 2008 tarihinde onaylanan çalışmamız; Temmuz 2009 - Ocak 2010 tarihleri arasında T.C.S.B. Etlik Zübeyde Hanım Kadın Hastalıkları Eğitim ve Araştırma Hastanesi IVF kliniğinde yapıldı. Çalışmaya kontrollü ovaryen hiperstimülasyon $(\mathrm{KOH})$ ve intrasitoplazmik sperm enjeksiyonu (ICSI) işlemi uygulanan 78 infertil çift dahil edildi.

Çalışmaya 20-40 yaş arası; erkek faktörü, açıklanamayan infertilite ve tubal faktör nedeniyle infertilitesi olan GnRH agonisti ile long luteal protokol kullanılarak $\mathrm{KOH}$ uygulanan hastalar dahil edildi. Çalışmaya dahil edilen hastalara $\mathrm{KOH}$ için rekombinant FSH içeren ilaçlar verildi.

Çalışmadan dışlanma kriterleri aşağıdaki gibi belirlendi:
1. Kötü over yanıtı olan hastalar; baskılanma öncesi FSH düzeyi $12 \mathrm{IU} / \mathrm{L}$ ve üzerinde olan, östradiol düzeyi $60 \mathrm{pg} / \mathrm{ml}$ üzerinde olan ve antral folikül sayısı her iki overde toplamda 6 ve altında olan hastalar,

2. Hipofiz baskılanması gününde yapılan ultrasonografide $10 \mathrm{~mm}$ ve üzerinde folikül kisti olan hastalar,

3. Sürekli ilaç kullanımını gerektiren sistemik hastalığı olan hastalar,

4. Mevcut tedavi öncesi 3 ay boyunca herhangi bir hormon tedavisi alanlar,

5. Geçirilmiş over cerrahisi olan hastalar,

6. Bazal serum prolaktin, fT3, fT4 ve TSH düzeylerianormalolan,polikistikoversendromu, hipofiz yetmezliği gibi endokrinolojik hastalığı olan hastalar,

7. Long luteal protokol dışında protokol kullanan hastalar ve rekombinan FSH dışında ilaç kullanan hastalar,

8. Oosit toplama işlemi ve embriyo transferi yapılamayan olgular,

9. $\mathrm{KOH}^{\prime} \mathrm{a}$ yanıtsız olan hastalar,

10. USG'de PCOS görünümü olan hastalar ( tek overde 10 ve üzerinde $2-10 \mathrm{~mm}$ folikülü olan hastalar),

Çalışmaya dahil edilen tüm olguların yaş, VKI, menstruel düzen, obstetrik ve jinekolojik özgeçmişleri kayıt edildi. Sekonder seks karakterlerinin değerlendirilmesi ve rutin pelvik muayeneyi takiben menstruel siklusun 2-3. günü TSH, fT3, fT4, FSH, LH, E2, P, Prolaktin düzeyleri ölçüldü; TVUSG ile uterus boyutları, endometrial kalınlık, over boyutları, antral follikül sayısı değerlendirildi. Bunun için Shimadzu SDU-450 XL marka ultrasonografi cihazı ve $8 \mathrm{MHz}$ 'lik vaginal prob kullanıldı.

Çalışmaya dahil edilen tüm hastalara, tedavi protokolü olarak GnRH agonisti kullanıldı. Oluşan hipofiz baskılanması ardından, $\mathrm{KOH}$ için rekombinan FSH kullanıldı. Hipofiz baskılanmasından önceki siklusun midluteal 
döneminde (adetin 21. gününde) GnRH agonisti (Lucrin ${ }^{\circledR}$ daily, Leuprolide asetat 0,5 mg; Abbott) subkutan (sc) başlandı. Hipofiz baskılanması sağlandığında (uterin kanama başladığında ve serum E2 seviyeleri $50 \mathrm{pg} / \mathrm{ml}$ altına indiğinde) agonist dozu yarıya düşülerek rekombinant FSH (rFSH) 150-225 IU/gün sc başlandı. Baskılanma gününde $\mathrm{FSH}$, LH ve E2 belirlendi. $\mathrm{Bu}$ dönemde hastalara antral folikül sayılarının belirlenmesi için transvajinal ultrason (TV-USG) yapıldı. Ovulasyon indüksiyonu rFSH (Gonal-F ${ }^{\circledR}$, Folitropin beta, Sereno Merck; Puregon ${ }^{\circledR}$, Folitropin beta, Merck Sharp) ile yapıldı ve doz ayarlaması seri USG ve E2 ile düzenlendi. Yarı doz GnRH agonisti verilmeye insan koryonik gonodotropini (HCG) gününe dek devam edildi. 3 adet folikül büyüklüğü $17 \mathrm{~mm}$ olduğunda HCG (Ovitrelle ${ }^{\circledast}$, koriogonadotropin alfa, Serono) 250 ug dozunda, subkutan uygulandı. Oosit toplanma işlemi HCG uygulanmasından 34-36 saat sonra intravenöz sedasyon altında TV-USG eşliğinde yapıldı. Sperm hazırlanması gradient yöntemiyle yapıldı. ICSI standart prosedürü uygulanarak elde edilen tercihen grade 1, iyi kalitede embriyoların 1-3 adeti, oosit toplanmasından 3-5 gün sonra transabdominal ultrasonografi rehberliğinde uterin kaviteye transfer edildi.

Tedaviye alınan hastaların bazal antral folikül sayımı aynı siklus içinde yapılmış ve bazal FSH ve E2 seviyeleri belirlenmiştir.

Tüm hastalara OPU gününde başlanarak luteal faz desteği \% 8'lik 90 mg Crinone vaginal jel 2x1 uygulanarak sağlandı. Gebe kalan olgularda vaginal progesteron desteğine 12. gestasyonel haftaya kadar devam edildi.

Tedavi sonuçlarını değerlendirmek için serum BHCG ölçümü transferin 12. günü yapıldı. İlk sonucu pozitif olan olgular 2 gün sonra konfirmasyon için tekrar çağrıldı. $\beta$ HCG'den 2-3 hafta sonra ultrasonografi ile görülebilen fetal kalp atımı varlığı klinik gebelik olarak tanımlandı.

Bazal antral folikül sayımı aynı kişiler tarafından erken foliküller fazda 2-10 mm arası foliküller dikkate alınarak yapıldı. Her iki overdeki foliküller toplanarak total antral folikül sayısı belirlendi. Baskılanma antral folikül sayısı ise hipofizer baskılanma gününde 2-10 mm arası foliküller sayılarak ve her iki overdeki folikül sayısı toplanarak belirlendi. Bazal FSH, LH ve E2 seviyeleri ve baskılanma günü $\mathrm{FSH}$, $\mathrm{LH}$ ve E2 seviyeleri ticari kitlerle (Roche) belirlendi.

Tüm hastaların stimülasyon süresince harcanan gonadotropin miktarları toplandı, stimülasyon süresi, toplanan oosit sayıları, matür oosit sayıları incelendi. Oosit kalite indeksi değerleri, 2PN sayısı, 2. gün, 3. gün ve 5. gün embriyo skorları hesaplandı. Stimülasyonun 4. günündeki E2 seviyeleri ve HCG günü E2 seviyeleri ticari kitlerle (Roche) bakıldı. Hipofizer baskılama günü ölçülen $\mathrm{FSH}$ ve $\mathrm{LH}$ değerleri oranlanarak yaş, bazal FSH, bazal LH, AFS, harcanan gonadotropin miktarı, stimülasyon süresi, toplanan oosit sayısı, matür oosit sayısı, oosit kalite indeksi, 2.gün, 3.gün ve 5.gün embriyo skorları, stimülasyonun 4. günündeki E2 seviyeleri ve HCG günü E2 seviyeleri, gebelik oranları arasındaki ilişki incelendi.

Bazal AFS, bAFS, bazal FSH, bFSH arasındaki korelasyonun belirlenmesindeki sonuç değişkenleri; harcanan gonadotropin miktarı, stimülasyon süresi, toplanan oosit sayısı, matür oosit sayısı, oosit kalite indeksi, 2. gün, 3. gün ve 5. gün embriyo skorları, stimülasyonun 4. günündeki E2 seviyeleri ve HCG günü E2 seviyeleri ve gebelik oranlarıdır.

İstatiksel analiz, Sosyal Bilimler için istatistik paketi 11.0 (SPSS 11 Windows Chicago) kullanılarak yapıldı. İstatiksel farklar Pearson korelasyon analiz testleri, örneklem iki T testi kullanılarak hesaplandı. $\mathrm{P}<0,05$ olması durumunda anlamlı farklılığın olduğu, $p>0,05$ olması durumunda ise anlamlı farklılığın olmadığı kabul edildi.

\section{BULGULAR}

Çalışmaya alınan ve $\mathrm{KOH}$ uygulanan 78 olgudan elde edilen veriler incelendi. Çalışmaya dahil edilen olgular için ortalama yaş $27,38 \pm 3,83$, vücut kitle indeksi (VKI) 25,02 $\pm 4,36 \mathrm{~kg} / \mathrm{m}^{2}$, infertilite süresi $71,92 \pm 51,79$ ay, bazal $\mathrm{FSH}$ değerleri $5,8 \pm 1,4 \mathrm{mIU} / \mathrm{ml}$, bazal E2 değerleri $45,33 \pm 27,7 \mathrm{pg} / \mathrm{ml}$, bazal LH 5,6 $22,5 \mathrm{mIU} / \mathrm{ml}$, 


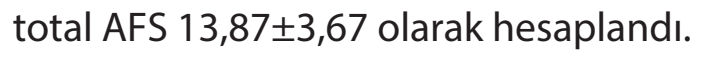

GnRH analoğu ile baskılanma gerçekleştikten sonra bakılan ortalama AFS (bAFS) 10,7 $\pm 3,9$,

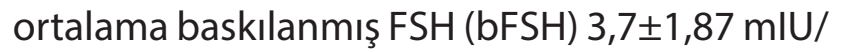
$\mathrm{ml}$ olarak bulundu. Ovulasyon indüksiyonu süresi $9,04 \pm 1,04$ gün olarak hesaplanırken; kullanılan gonodotropin miktarı ortalama $1837,5 \pm 462,8$ IU olarak bulundu. Tüm hastaların baskılanma günü, stimülasyonun 4. günü ve HCG günü ortalama E2 seviyeleri sırasıyla; $17,2 \pm 14,6 \mathrm{pg} / \mathrm{ml}, 419,6 \pm 376,73 \mathrm{pg} /$ $\mathrm{ml}, 2504,02 \pm 1265,9 \mathrm{pg} / \mathrm{ml}$ ve ortalama klinik gebelik oranları \% 37,1 olarak hesaplandı.

HCG uygulandıktan 36 saat sonra ultrasonografi eşliğinde yapılan folikül aspirasyonu sonrası toplanan oosit sayısı ortalama 15,5 $\pm 7,2$, matür oosit sayısı ortalama $11,88 \pm 6,07$ olarak bulundu. Oosit kalite indeksi $>5$ olan oosit sayısı \% 78,7 olarak hesaplanırken; 2., 3., 5. gün embriyo skorları sırasıyla 4,35 $\pm 0,60,4,12 \pm 0,65$, $3,76 \pm 0,69$ olarak bulundu. Ortalama 2 PN sayısı $6,5 \pm 4,2$ olarak hesaplandı.

Bazal antral folikül sayısı ve hipofizer baskılanma sonrası bakılan antral folikül sayısı ile hastaların yaşı ve hormonal değişkenleri arasındaki ilişki bivaryant korelasyon analizi ile hesaplandı. Kadın yaşı ile bazal AFS ve bAFS arasında negatif korelasyon saptandı. Kadın yaşı arttıkça AFS sayısının azaldığı görüldü. Bu ilişki istatistiksel olarak anlamlı değildi $[(r=-0,04 ; p=$ $0,71) ;(r=-0,11 ; p=0,30)]$. Bazal AFS ve bAFS ile FSH ve baskılanma sonrası FSH düzeyleri, 4. gün ve HCG günü E2 ilişkisi istatiksel olarak anlamlı bulunamadı $(p \geq 0,05)$.

Bazal, hipofizer baskılanma sonrası bakılan AFS, $\mathrm{FSH}$ ve $\mathrm{FSH} / \mathrm{LH}$ oranları ile $\mathrm{KOH}$ süresi, kullanılan toplam gonodotropin miktarı, matür oosit sayısı, toplam oosit sayısı ve oosit kalite indeksi arasındaki ilişki bivaryant korelasyon analizi ile hesaplandı. Bazal FSH ile $\mathrm{KOH}$ süresi arasında istatistiksel olarak anlamlı pozitif korelasyon saptandı $(r=0,22 ; p=0,04)$. Bazal FSH arttıkça $\mathrm{KOH}$ süresinin uzadığı gözlendi. Kullanılan toplam gonadotropin miktarı ile bazal AFS arasında negatif korelasyon saptandı. Bazal AFS arttıkça kullanılan gonadotropin miktarının azaldığı gözlendi. Bu ilişki istatistiksel olarak anlamlıydı $(r=-0,30 ; p=0,007)$. TOS, MOS, OKI ile bazal AFS, bazal FSH, bazal FSH/LH, bAFS, bFSH, bFSH/LH değerleri arasında istatistiksel anlamlı korelasyon saptanmadı $(p \geq 0,05)$.

Bazal AFS, bAFS, bazal FSH, bFSH, bazal FSH/LH, bFSH/LH ile 2PN sayısı ve 2., 3., 5. gün embriyo skorları arasında bivaryant korelasyon analizi yapıldı. Bazal FSH ile 2 PN arasında negatif korelasyon saptandı. Bazal FSH arttıkça 2PN sayısının azaldığı gözlendi. Bu sonuç istatistiksel olarak anlamlı bulundu ( $r=-0,27 ; p=0,01)$. Bazal AFS, bazal FSH, bazal FSH/LH, bAFS, bFSH, bFSH/LH değerleri ile 2PN sayısı ve 2., 3., 5. gün embriyo skorları arasında istatiksel olarak anlamlı korelasyon izlenmedi ( $p \geq 0,05)$.

Hipofizer baskılanma öncesi ve sonrası AFS yüzde değişimleri hesaplandı. AFS'daki azalmanın en az \% 8,33, en fazla \% 75 olduğu izlendi. Ortalama değer \% 26,6 olarak bulundu. Baskılanma yüzdesine göre sonuçların farklılığını değerlendirmek için hastalar hipofizer baskılanma yüzdesi ortalama değerlerine göre iki gruba ayrıldı. Grup I: Hipofizer baskılanma sonrası AFS'da \% 26,6'dan daha az baskılanma olan hastalar (n:40). Grup II: Hipofizer baskılanma sonrası AFS'da \% 26,6'dan daha fazla baskılanma olan hastalar (n:38) Grup I ve II'nin embriyolojik data verilerinin tanımlayıcı istatistik verileri saptandı (Tablo 1).

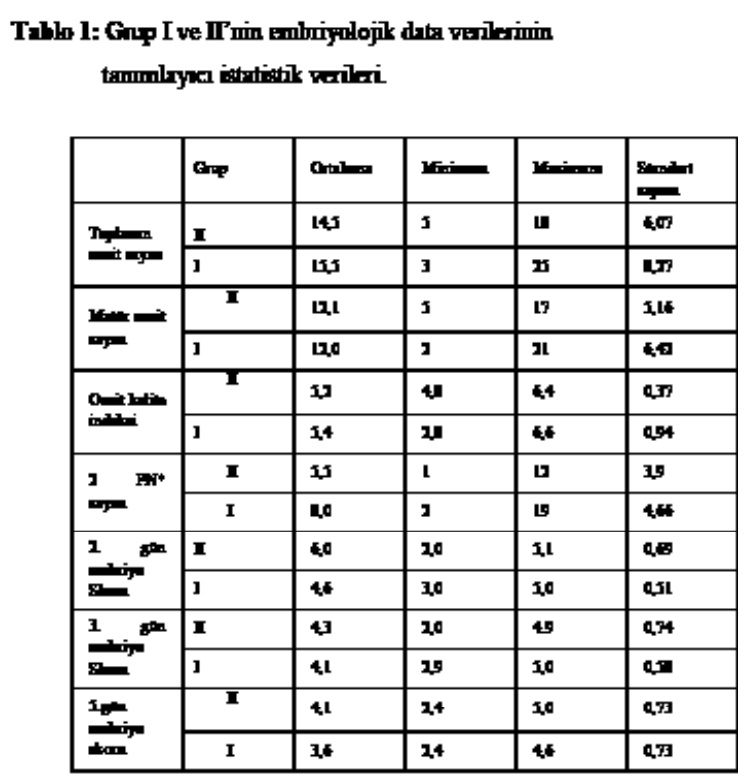

*2 FN [2 prondeus\} 
Bağımsız 2 örneklem T-Testi kullanılarak yapılan istatistik analizinde; TOS, MOS, OKI, 2PN değerleri, 2., 3., 5. gün embriyo skorları bakımından iki grup arasında anlamlı fark saptanmadı $(p \geq 0,05)$.

\section{TARTIŞMA}

Scott ve arkadaşlarının 1989 yılında yayınladıkları 3. gün basal FSH değerlerinin IVF sikluslarında over rezervini öngörmesi ile ilgili çalışma ile infertil hastaya yaklaşımda yeni bir dönem başlamıştır. Takip eden yıllarda 3. gün serum hormon değerleri ile ilgili sayısız çalışma yapılmıştır. Günümüzde halen infertil çifte yaklaşımda bazal serum hormon değerleri, bazal ultrasonografi ile ovaryen foliküllerin değerlendirilmesi ilk basamakta yerini korumaktadır (3).

Onagawa ve arkadaşlarının 2004 yılında 59 infertil hastanın 72 IVF siklusu dahil edilerek yaptığı bir çalışmada; hipofizer baskılanma günü stimülasyon öncesi ROC eğrileri ile FSH eşik değeri 5,25 IU/ml olarak belirlenmiş ve bu değerin üstünde toplanan oosit sayısı ve OHSS gelişme olasılığı düşük bulunmuşken, bu değerin altında her ikisi de yüksek bulunmuştur (4).

Ping Ho ve arkadaşlarının 2005 yılında 245 IVFICSI siklusunu içeren bir çalışmalarında $\mathrm{GnRH}$ analoğuilebaskılanma esnasında,gonadotropin stimülasyonu başlamadan önce ölçülen serum $\mathrm{FSH}$ ve FSH/LH oranlarının toplanan matür oosit sayısı ile ters korelasyon gösterdiği saptanmıştır (r:-0,193 ve r:-0,224). FSH/LH oranlarının normal ve zayıf cevaplı hastaları belirleyebileceği belirtilmiştir. ROC analizi kullanılarak bulunan eşik değere göre; $\mathrm{FSH} / \mathrm{LH} \geq 3$ ise, daha az matür oosit toplandığı $(8,25$ vs. 11,74), daha düşük E2 seviyeleri $(1,975,3 \mathrm{pg} / \mathrm{mL}$ vs. 3,324,8 pg/mL), ve zayıf cevaplı siklusların daha yüksek oranda olduğu saptanmıştır (\% 32,5 vs. \% 14,3). Sonuç olarak gonadotropin stimülasyonu öncesinde baskılanma sırasındaki FSH/LH oranının toplanan matür oositi erken predikte etmede pratik bir yöntem olduğu savunulmuştur (5).

Penarrubia ve arkadaşlarının 2010 yılında 98 infertil hasta grubunda yaptığı bir çalışmada ise; GnRH agonist kullanılan IVF sikluslarında hipofizer baskılanma sırasında ölçülen AFS ve
5. Gün inhibin-B serum konsantrasyonlarının ovaryen cevabı ve gebelik sonuçlarını öngörmedeki rolleri araştırılmış ve ovaryen stimülasyona cevapta, bazal değişkenler içinde AFS; dinamik hormon ölçümleri içinde ise inhibin-B ovaryen yanıtı öngörmede en başarılı testler olarak bulunmuştur. Ovaryen yanıtı belirlemede her iki ölçümün sonuçları benzer bulunmuştur (6).

Melovearkadaşlarıtarafında2009yılındayapılan bir çalışmada; hipofizer baskılanma esnasındaki AFS $\leq 10$ ise, siklus iptal oranları daha fazla, toplanan matür oosit sayısı daha az, HCG günü estradiol ve en yüksek estradiol seviyeleri daha düşük saptanmıştır. AFS $\leq 10$ siklus iptal oranları daha fazla olmasına rağmen aynı gebelik oranları tespit edilmiştir. Sonuç olarak; düşük AFS KOH'a zayıf yanıtı belirler ancak kötü oosit kalitesini öngöremez denilmiştir. Bu çalışmanın sonucundan yola çıkarak kendi kliniklerinde AFS $\leq 10$ olan hastalara $\mathrm{KOH}$ için gonadotropin ilk dozunu 300IU/gün ile başladıklarını, AFS $\geq 17$ olan hastalara ise 150lU/gün ile başladıklarını belirtmişlerdir (7).

Bizim çalışmamızda hipofizer baskılanma esnasındaki AFS ve bazal AFS'nin matür oosit sayısı, oosit kalite indeksi, kullanılan gonodotropin süresi, toplam oosit sayısı, 2PN sayısı, 2., 3., 5. gün embriyo skorları ile bivaryant korelasyon analizi yapılarak sonuçlar karşılaştırıldı. Kullanılan toplam gonadotropin miktarı ile bazal AFS arasında negatif korelasyon saptandı. Bazal AFS arttıkça kullanılan gonadotropin miktarı azaldığı izlendi. Bu ilişki istatistiksel olarak anlamlı olarak saptandı $(r=$ -0,30; $p=0,007$ ). bAFS ile siklus performans parametreleri arasında istatistiksel olarak anlamlı korelasyon saptanmadı $(p \geq 0,05)$.

Bazal AFS ve baskılanma günü ölçülen AFS arasında yüzde değişim hesaplanarak; minimum $\%$, maximum \% 35, ortalama \% 26,6 azalma tespit edildi. Yüzde değişim oranlarına göre iki grup oluşturuldu (Grup I: AFS'da baskılanma \% 26,6'dan daha az, Grup II: AFS'da baskılanma \% 26,6'dan daha fazla). Gruplar;TOS, MOS, OKI, 2PN sayısı, 2., 3., 5. gün embriyo skorları bakımından bağımsız 2 örneklem T-Testi kullanılarak karşılaştırıldı. İstatistiksel olarak anlamlı bir fark saptanmadı $(p \geq 0,05)$. bAFS'ye bir eşik değer 
bulmak için yapılan ROC analizinde istatistiksel anlamlı sonuçlar elde edilemedi.

Sonuç olarak; IVF sikluslarında normal cevaplı olduğu kabul edilen, GnRH long luteal agonist protokolü başlanılan vakalarda bAFS, bFSH ve bFSH/LH değerleri ile bazal AFS; bazal FSH, bazal FSH/LH arasında siklus performansını öngörmede anlamlı bir fark olmadığı sonucuna varıldı.

\section{KAYNAKLAR}

1. Kahraman S, Yakın $\mathrm{K}$ (Editörler). Over rezervinin değerlendirilmesi. Ovulasyon indüksiyonu. İstanbul, 2000;20-32.

2. Johnson NP, Bagrie EM, Coomarasamy A, et al. Ovarian reserve tests for predicting fertility outcomes for assisted reproductive technology: the International Systematic Collaboration of Ovarian Reserve Evaluation protocol for a systematic review of ovarian reserve test accuracy. $\mathrm{Br} J$ Obstet Gynecol 2006;113 (12):1472-80.

3. Scott RT, Toner JP, Muasher J et al. Follicle stimulating hormone levels on cycle day 3 are predictive of in vitro fertilization outcome. Fertil Steril 1989;51 (4):651-4.

4. Onagawa T, Shibahara $\mathrm{H}$, Ayustawati et al. Prediction of ovarian reserve based on day-3 serum follicle stimulating hormone concentrations during the pituitary suppression cycle using a gonadotropin releasing hormone agonist in patients undergoing in vitro fertilization. Gynecol Endoc 2004;18 (6):335-40.

5. Ho JY, Guu HF, YiYC et al.. The serum follicle-stimulating hormone-to-luteinizing hormone ratio at the start of stimulation with gonadotropins after pituitary downregulation is inversely correlated with a mature oocyte yield and can predict "low responders". Fertil Steril 2005;83 (4):883-8.

6. Peñarrubia J, Peralta S, Fábregues F et al. Day-5 inhibin $B$ serum concentrations and antral follicle count as predictors of ovarian response and live birth in assisted reproduction cycles stimulated with gonadotropin after pituitary suppression. Fertil Steril 2010;94 (7):2590-5.

7. Melo MA, Garrido N, Alvarez C, Bellver J, Meseguer M, Pellicer A, Remohi J. Antral Follicle Count (AFC) can be used in the prediction of ovarian response but cannot predict the oocyte/embryo quality or the in vitro fertilization outcome in an egg donation program. Fertil Steril 2009;91(1):148-56. 